\title{
Keeping the dream alive: the European Court of Justice and the transnational fabric of integrationist jurisprudence
}

\author{
ANTOINE VAUCHEZ* \\ Research Professor, Centre Européen de Sociologie et de Science Politique (CESSP), Université Paris 1-Sorbonne, \\ Paris, France
}

How does the European Court of Justice (ECJ) firmly maintain a now 45-year-old consistent integrationist jurisprudence when exerting virtually no control over the recruitment of its members (a selection left to national governments)? Rather than considering such judicial consistency over time as a 'given', the paper questions the social fabric of judicial preferences. On the basis of a variety of commemorative materials produced within the Court (Festschriften, tributes, eulogies, and jubilees) and never studied so far, the paper stresses the manner in which these rituals are home to social processes of aggregation (into one unique judicial family), demarcation (from the political realm), and self-identification (to roles of so-called 'founding father', 'current spokesmen', or 'would-be judges'), thereby enabling transnational role transmission within international courts such as the ECJ.

Keywords: European Court of Justice; transnational elites; political sociology

\section{Introduction}

The permanence of the European Court of Justice's (ECJ) integrationist jurisprudence over the past decades is a widely acknowledged feature of European Union (EU) integration accounts (see recently, Cichowski, 2007; Conant, 2007; Scharpf, 2009; Stone, 2010). Most legal and political science studies indicate that, ever since its landmark decisions delivered in 1963 (Van Gend en Loos) and 1964 (Costa vs. ENEL), the ECJ ${ }^{1}$ has continuously used its power to widen and deepen the scope of EU regulations. ${ }^{2}$ In a context where Member States have repeatedly refused to authenticate its core jurisprudential acquis ('direct effect' and the

* E-mail: antoine.vauchez@univ-paris1.fr

${ }^{1}$ For the sake of clarity, I will use the terms ECJ, the European Court, and the Court of the Justice of the European Union (CJEU) on the one hand, and European law, EU law, or European Court (EC) law on the other, interchangeably.

2 This is not to say that there has been no variation in the Court's jurisprudence across and within policy areas, but rather to point to the overall consistent pro-integration stance of the Court. Among recent examples of such a continuity, see the ECJ's much debated Kadi decision, considered as 'a direct, if late, offspring of the van Gend en Loos and Costa vs. ENEL jurisprudence' (Gattini, 2009: 224). 
'supremacy' of EC law) ${ }^{3}$ in the black and white of treaties, the Court has kept promoting the steering potential of these early verdicts. And yet it has undergone stringent changes from the eight reform treaties that have marked its existence to the six waves of enlargement, including the recent near doubling of the Court's membership within a span of merely 3 years (2004 and 2007). How is it then that a Court whose jurisdictions (from 1 to 3 ), judges (from 7 to 61), nationalities (from 6 to 27), and competences (from coal and steel to an almost general competence) have evolved in such a dramatic manner can actually act as one unique entity, endlessly developing the same integrationist jurisprudence? The enigma is all the more salient given that the Court lacks a supranational judicial profession from which to recruit new members socialized to its core legal principles. ${ }^{5}$ Strangely enough, such a research puzzle has essentially remained unaddressed: the neo-rationalists and neo-institutionalists that have dominated the study of the ECJ in the realm of political science have, so far, taken 'the Court' as their basic unit of analysis without ever questioning its very existence as one cohesive entity (for a review, see Conant, 2007; for a critique, Vauchez, 2010b). Although they may disagree about whether the ECJ is an agent of the Member States or a more independent and strategic actor, they assume the existence of a Court, analyzed in an anthropomorphic manner, that is, as a unitary and transhistorical collective with a clear-cut idea of its own interests in EU politics (for a recent critique, see Granger, 2009; Grimmel, 2010). Yet, there are no accounts as to how such a diverse group of 27 judges from different European countries with distinct legal traditions and professional backgrounds would spontaneously and continuously converge on what a 'rational' judicial decision means for the Court. Rather than taking such convergence in preferences for granted and treating the Court in abstracto, this paper questions the social fabric of judicial preferences. ${ }^{6}$ The underlying idea is that by understanding how ECJ judges are socialized to the jurisprudential acquis, we may gain additional purchase as to how they then maintain a consistent jurisprudence. I hypothesize that such continuity over time

\footnotetext{
3 The story repeated itself when the 'supremacy' principle - which had been explicitly written into the treaty establishing a European Constitution - was removed and relegated to a Protocol to the Lisbon treaty.

${ }^{4}$ A variety of indicators actually suggest that the consequences of the 2004 and 2007 enlargements in terms of the unity and stability of the Court were viewed with great concern by many Court officials. Although a variety of judges and former judges have voiced their concern for the continuity of 'the internal culture of the Court' (judge Timmermans quoted in Rasmussen, 2007: 1662), the Court indicated in a report that 'a significant increase in the number of judges might mean that the plenary session of the Court would cross the invisible boundary between a collegiate court and a deliberative assembly' (CJEC, 1995).

${ }^{5}$ It must be said, however, that the new recruitment procedure established by article 255 of the Lisbon Treaty may have unexpectedly important consequences. The first accounts of the advisory expert panel, in part 'chosen from among former members of the Court of Justice and the General Court' and presided over by the president of the ECJ, indicate that it has already been followed when it gave negative opinions on 'the suitability of the candidates (Petkova, 2010; Burrows, 2010).

${ }^{6}$ For a broader overview of this research path, see Vauchez (2010b).
} 
is rooted in a transnational judicial esprit de corps that has been continuously maintained and revived over time by a select group of centrally placed ECJ judges. As there is no structured EU judicial profession, I consider in this paper the specific forms under which such esprit de corps and the related professional socialization is built in Luxembourg. To this end, I explore new empirical materials by inquiring into the various commemorative venues (eulogies, jubilees, Festschriften) that have developed within the ECJ since the 1970s. These are not necessarily the primary site of socialization at the Court. Yet, as they constitute institutional rituals allowing for 'the Court' to secure consistency, heterogeneity, and external challenges, they are a propitious entry point to observe role transmission. While these occasions publicly stage the cohesiveness and shared beliefs of the EU judicial 'community' of practitioners across its many national, generational, and professional (judges, law clerks, external EU law 'public') divides, they concurrently allow social exchanges among their participants through which 'founding fathers', 'current spokesmen', and 'putative heirs' are selected, co-opted, and authenticated.

The remainder of the article is organized in the following way. First, I discuss the conventional explanations for judicial consistency and indicate the analytical conceptual framework for this research (and the related empirical strategy) based on the social fabric of judicial preferences. In the second section, I point to the development of commemorative venues as an institutional ritual where (former, current, and future) judges are called upon to praise the Court's 'original prophecy' - that is, the Van Gend en Loos and Costa vs. ENEL decisions (1963-64). Engaging in a fine-grained analysis of these rituals, I then identify three distinct, yet interdependent, processes through which roles are instilled and transmitted: first, commemorations symbolically aggregate (former, current, and would-be) judges that are called upon to unite in one judicial 'family' with a distinct mission, that of protecting the jurisprudential acquis of the golden years against potential threats coming from the political realm; second, eulogies and Festschriften are home to a division of roles - from 'founding fathers', current 'spokesmen', or 'putative heirs' - with which judges or would-be judges are incited to identify; last but not least, the continuous revival of the Court's tradition enables the informal codifying of the set of credentials and specific assets any future ECJ judge is expected to possess in order to perform his role at the Court authoritatively.

\section{The social-fabric approach to courts}

Although it is still referred to as the 'European Court', the ECJ has undergone drastic transformations throughout the nearly six decades of its existence, moving away from the small, stable, and cohesive milieu of legal professionals that had coalesced with its founding decisions - Van Gend en Loos (1963) and Costa c. ENEL (1964). Ever since the departure of a small group of judges and référendaires who had been closely linked with the consolidation of the "Van Gend en 
Loos-Costa doctrine" ${ }^{, 7}$ in the 1960s, the stability and relative homogeneity of the Community's judiciary gave way to an increasingly mobile and diverse group (Vauchez, 2010b). Indeed, throughout the five Community enlargements and the subsequent increase of its caseload, the ECJ has experienced an ongoing process of internal differentiation that has transformed the Court into a complex organization made up of a number of institutions (the Court of Justice, the Court of First Instance created in 1991, and the Civil Service Tribunal), judges (from a group of 13 from nine Member States in the mid-1970s to a group of 70 from 27 Member States today), associations (the Amicale des référendaires et anciens référendaires created in 1991, the permanent delegation to the Court of Justice of the Council of European Bar associations and Law societies, etc.), and specialized professional groups (Schepel and Wesseling, 1997; Alter, 2008; Vauchez, 2008a; Cohen, 2010). Such transformations came with an increasing turnover: although only two judges were leaving the ECJ every 3 years during the 1950s, 1960s, and 1970s, the average rate of departure rose to two per year in the 1980s and 1990s, and to more than three per year in the past decade. Such instability was made even more obvious by the fact that the group of référendaires, until then regarded as the permanent figures of the institution, not only grew in number to more than 200 members (Grass, 2006: 76), but also lost their stability as their time in office drastically fell to 5 years on average in the late 1990s (Kenney, 1998). What is it then that makes the Court's jurisprudence so consistent over time when it is grounded on such shaky foundations? The general scholarly study of judicial decision-making in the realm of political science suggests at least three conventional explanations to the puzzle of case-law stability.

The first, promoted by neo-rationalists, regards such consistency as essentially unproblematic. Although it is well known that the Court has been a bone of contention between the competing inter-governmentalist and neo-functionalist theories of integration (for recent accounts, see Conant, 2007; Stone, 2010), both converge in viewing it as a unitary actor driven by pre-existing preferences (the continuous expansion of its pan-European jurisdiction), rationally pursuing its interest in front of a variety of external constraints (Garrett, 1995; Garrett et al., 1998; Alter, 2001; Carubba et al., 2008). All in all, none of these streams of research questions how these preferences were initially produced, nor how they are transmitted to new members of the Court and, thereby, perpetuated. Yet, there are good reasons to doubt that judicial preferences constitute an ahistorical 'given' independent from the changing set of national, professional, and political backgrounds of the judges themselves (Jenson and Mérand, 2010). In the same vein, it is quite safe to hypothesize that, absent a supranational judicial professional able to

\footnotetext{
7 The mid-1970s are critical in this regard. Within 3 years, four of the judges from the 'revolutionary period' had reached the end of their mandate. The departure of the two Italian judges Roberto Monaco and Antonio Trabucchi was followed by that of both presidents from that period (1958-76), Andreas Donner and Robert Lecourt, who left the Court in 1976 and 1979, respectively.
} 
train and instill core values and beliefs, ECJ judges do not spontaneously converge on how the prestige and the independence of the Court should best be promoted. In particular, such rationalist explanations fail to account for why the ECJ has maintained and even pushed its constitutional and pan-European jurisprudence in a number of recent groundbreaking decisions - from Kadi to Laval and Viking - while at the same time nearly doubling the number of its members following the last waves of EU enlargement (Grass, 2006; Rasmussen, 2007).

The second explanation points at the particular relevance of path-dependent mechanisms in the realm of judicial decision-making. It is well known that judges, both in civil law and in common law systems, value references to previously established legal principles and tend to frame their own judgments within the boundaries of precedents (be they labeled stare decisis or jurisprudence constante, depending on the specifics of one's national legal culture). Alec Stone has authored interesting pages on the development of precedent-based practices in the case of the ECJ, with Van Gend en Loos (1963) standing out as the critical juncture, and the EU litigation arena being the site of a long-term self-reinforcing process (Stone, 2004: 30-41). Recently, legal scholars have pointed at the existence of a 'judicial style' specific to the ECJ (Azoulai, 2009) in order to frame their legal suits authoritatively, Euro lawyers need to draw from a limited set of previously established legal sentences that form the commonly accepted bricks of EU law reasoning (Bengoetxea, 1993). However, the fact that EC lawyers do not work in an unpredictable and chaotic manner is not enough of an explanation when it comes to understanding why and how 'the Court' maintains and repeatedly revives its pan-European agenda. Institutions and professional roles do not hold by themselves, nor do they have a life of their own, unless their underlying creeds and credos are perpetuated and revitalized through continuous social and political mobilizations. By insisting essentially on the endogeneous dynamics of EC judicial decision-making, this neo-institutionalist account therefore overestimates the inherent stability of the judicial process itself.

There is, however, a third possible explanation for our puzzle, partly related to the previous one. It points at 'role transmission' within the court itself. According to this thesis, courts hold their jurisprudence constant because newcomers to the judicial office are incited through a variety of means to embrace the new professional role, progressively embodying the behavior and worldviews expected from anyone taking over such a position. Lisa Hilbink recently tested such a causal mechanism in the case of the Chilean judiciary, explaining the persistence of a specific pattern of judicial behavior across regime change 'through the watchful eye of the Supreme Court' responsible for lower judges' appointment and promotion (Hilbink, 2007). Granted, institutional roles do matter, but how is it that such professional codes and canons are built and instilled in the case of international courts for which there is no such thing as a supranational recruiting and training system able to set and diffuse shared beliefs and common understandings to newcomers? Contrary to their national counterparts, international judges such as the European ones cannot rely on a professional body of judges, or 
even a 'feeder' court where future members would be socialized and selected. Studies show that there are as many breeding grounds and criteria for selecting judges as there are countries to EU treaties (Kenney, 1998; Cohen, 2008, 2010; Voeten, 2007; Terris et al., 2007), each country seeking to 'balance a different constellation of interests and cleavages in choosing its members of the ECJ, such as party, language, region, legal system, and governmental department' (Kenney, 1998: 108). True enough, one could argue that an increasing number of ECJ judges have had some national training or/and professional experience in the realm of EC law. National socialization to the Court's jurisprudence would then secure newcomers' lasting support for core ECJ legal principles. ${ }^{8}$ Yet, such an argument does not account for the fact there is still a 'nationally colored outlook on EU law (de Witte, 2008) impeding any form of cognitive mainstreaming. In this, international courts differ from national constitutional courts. Even though they also lack a proper profession from which to recruit members, they are not confronted with such heterogeneity, as judges are mostly drawn from the national bar's or law schools' elite, trained within the same legal culture. To put this in the terms of the sociology of professions, international courts lack the supranational professional body able to set common educational requirements and establish an institutionalized 'control over the production of producers'.

To answer the enigma of judicial consistency at the ECJ, it therefore proves necessary to break open a renewed conceptual framework equipped to track the social fabric of jurisprudence. This perspective draws on the recent political sociology stream of research in EU studies that criticizes rational-choice institutionalism for treating institutions as formal, free-floating, and disincarnated institutions with abstract interests (Vauchez, 2008b; Cohen and Vauchez, 2010; Georgakakis, 2010; Mangenot and Rowell, 2010). In line with these developments, I suggest a more sociologically informed understanding that considers the ECJ as a specific site of contention where a number of legal professionals contend over the definition of its nature and future, including the most convenient direction for its jurisprudence, the most relevant type of know-how and credentials to persuasively perform EU judicial office, the priorities for its future organizational reform, etc. In other words, the social-fabric approach does not take 'the Court' its 'interests', 'mandates', and institutional 'identity' - as a premise of the analysis. Rather, the very aim of the inquiry is to trace the social process through which these are produced and reproduced over time. In the case of the European Court of Justice, I have, elsewhere, traced the genesis of such an institutional identity and the related constellation of actors supporting it back to the Van Gend en Loos and Costa vs. ENEL decisions. Then, a variegated set of pan-European legal professionals, including the Commission's legal service, the legal section of the pan-European movement (the so-called Fédération internationale pour le droit européen-FIDE)

\footnotetext{
${ }^{8}$ For a similar argument in the case of socialization to the European Commission, see Lisbet Hooghe (2005).
} 
and a select group of ECJ judges, coalesced around the promotion of the Court's jurisprudential 'coup', thereby defining the EU judicial branch as both the pillar and the engine of European integration (Vauchez, 2010a). This is not the place to return to these circumstances. Suffice it to say that EU jurisprudence did come about as a mere set of legal principles, but concurrently emerged as a distinct social and professional constellation and an underlying system of meaning concerning the Court's role in the Europeanization processes.

The social-fabric approach takes as its object of inquiry the process of socialization to such historically built social and cognitive systems. The related empirical strategy therefore tracks the social mechanisms through which the Court's institutional identity has been maintained and inculcated over time. Such questioning is all the more intriguing given that, in the particular case of courts, role transmission happens under constraining circumstances. Judges' margins of maneuver are quite narrow in a milieu - that of law - which draws much of its authority from displaying neutrality (Bourdieu, 1987; Dezalay and Garth, 1996). As a result, judges - and, in particular, international judges - very seldom engage in overtly professional mobilizations that would undermine their own specific legitimacy (Mcintosh and Kates, 1997). ${ }^{9}$ There are therefore good reasons to believe that most socialization happens behind closed doors, within the Court itself. Just like in any other institution, informal meetings in the corridors or discussions in the canteen are likely to constitute essential socialization loci. In particular, the sociability of référendaires across cabinets could be studied in such a perspective, as they are home to discussions over ongoing judgments and, more importantly, to a general mainstreaming of the cognitive and normative frames used to evaluate legal issues and individual professional moves. ${ }^{10}$ The changes in the Court's organization since the Nice Treaty and the subsequent concentration of judge-making power in the hands of the presidents of the three five-member Chambers and the Grand Chamber could be an equally interesting entry point (for an interesting analysis in this direction, see Petkova, 2010). ${ }^{11}$ Last but not least, formal instruments - such as legal databases or internal vademecum - are also essential channels of socialization. As they include routinized legal formulas,

\footnotetext{
${ }^{9}$ Laurent Scheeck has also thoroughly exemplified how academic conferences have become an essential forum for 'diplomatic' discussions between European Court of Human Rights and ECJ judges concerning their respective roles in building a European-wide protection of human rights (Scheeck, 2010).

${ }^{10}$ It could be argued, for example, that the integrative capacity of the Court during the two recent waves of EU enlargement has to do with the role played by experienced référendaires from old member States strategically placed in the cabinets of Eastern and Central European judges.

11 Since the Nice Treaty (2000), the ECJ has been composed of three five-member Chambers and one Grand Chamber whose presidents are elected every 3 years, therefore adding to the traditional election of the presidents of the three jurisdictions composing the ECJ. It does take a political scientist to assume that some degree of informal electoral politics is involved. Drawing from the 'names and known judicial orientations and philosophies' of the four elected presidents, Hjalte Rasmussen actually argues that a 'federalist coup' occurred during the October 2004 election as three of them were of strict federalist creed, thereby maintaining a strong hold on the Court (Rasmussen, 2007).
} 
keywords, and standardized forms of judgments that have been framed over the decades, in-house software and guidelines are certainly also decisive in socializing newcomers to a set of previously established legal alternatives and debates. ${ }^{12}$ Yet accessing the internal functioning of the Court in the way Bruno Latour was allowed to do at the Conseil d'Etat (Latour, 2009) ${ }^{13}$ remains a far remote perspective in Luxembourg. The ECJ has indeed not only remained strikingly silent about its decision-making process (absence of dissenting opinions, non-publication of reports of hearings, etc.), but has also more generally maintained a strenuous secrecy concerning its internal functioning (non-disclosure of archive). ${ }^{14}$ It takes some shrewdness on the part of the researcher to circumvent such a lack of access. Among the few possible empirical options (see also the interesting empirical material gathered by Petkova, 2010), commemorations, be they Festschriften, tributes, eulogies, or Courts' jubilees ${ }^{15}$ constitute an interesting and so far neglected entry point. As indicated above, they are probably not the essential, nor the primary locus of ECJ judges' socialization. Yet, I will argue hereafter that the commemorative empirical corpus makes for a propitious and original terrain of inquiry in order to address the puzzle of the ECJ's case-law consistency over time and across policy domains.

More often than not, these commemorative venues are viewed as selfpromotional instruments through which Court officials engage in some sort of public relations strategy. I would actually argue the contrary. There are indeed good reasons to believe there is more to these venues than mere legitimatory devices or, worse, mere smokescreens. One indicator of this lies in the fact that, although they are of almost no legal value and are time consuming, they are, however, organized with great care and remain very popular. To be sure, creating and publishing Festschriften involves a whole economy of effort and investments such as 'initiating, commissioning, composing, compiling, editing, proof-reading, and generally organizing the volume prior to publication' (Macalister-Smith and Schwietzke, 2002: 369; see also Taggart, 2002). Most of the time, it also requires the launch of a subscription among contributors and others, engagement in fundraising to finance these usually very long volumes (there are often two volumes or more) and often the organization of a presentation ceremony. Moreover, such tasks involve not only a group of authors - from 20 to 98 in this case - and some members of the secretariat, but also an editorial team and an honorary committee in

12 See, for example, the systematic codification of the ECJ 'judicial style' undertaken by the then ECJ judge Pierre Pescatore (1985, first published in 2007).

13 On specific empirical strategies for entering courts' 'closed chambers', see the remarks of Sally Kenney on the US Supreme Court (2000).

14 Even though a legal framework for the disclosure of archives has actually existed since February 1983 (Regulation (no. 354/83) and a December 1984 Contract foreseeing the depositing of the Court's archives in the Historical Archives of the European Communities), the ECJ has never opened any of its internal documents to the public.

15 Similar commemorative strategies have been noted in the case of the European Court of Human Rights, see Hennette-Vauchez (2008). 
charge of supervising the publication process. And yet neither eulogies nor Festschriften correspond to any of the traditional formats valued for their legal or judicial contributions: they are neither procedural acts (such as opinions of the advocate general or conclusions of reporting judges), nor are they case-notes. Rarely read (as they are often edited by publishing houses of secondary importance), not readily available, Festschriften are best described as 'graveyards of scholarship' (quoted in Melchior, 1962: 410). In such a context, the general willingness to participate in such ungratifying volumes, as well as the great care with which both eulogies and Festschriften are organized, is indicative of the fact that there is more to these publications than just a formal celebration of the addressee. In many regards, these commemorations are indeed authentic institutional rites. They are the one rare occasion when 'the Court', or at least a large part of its members, is publicly brought together. Moreover, a great deal of attention is paid to specific ceremonial rules, whether through the so-called 'formal sittings' of the Court or through the very formalized editing process of Festschriften (on such formal rules, see MacalisterSmith and Schwietzke, 2002). Drawing from the abundant literature on the sociology of rituals (Mauss, 1897, 1898, Bourdieu, 1971; Espeland and Halliday, 1994), I contend they are home to two essential and interrelated phenomena: the codification of the impersonal and ahistorical features of the institution through the exaltation of the departing judges and the social stratification of the related milieu of professionals through the position each of the participants is given throughout the ceremony itself. To put it differently, they are critical venues for the symbolic maintenance of international courts; and, at the same time, as they are invitation-only circles, they also provide an opportunity to select and authenticate 'founding fathers', institutional leaders, and putative heirs faithful to the Court's core principles. For this reason, these celebrations - which could appear as purely idiosyncratic in that they refer to the profile of the addressee, the specifics of a given moment in history, and the singularity of the genre (discourse, written article, short biographical note, etc.) - are integral to the reviving and the transmission of the Court's institutional identity as a whole. ${ }^{16}$

\section{Inventing tradition: legal landmarks and the building of a transnational judicial community}

Commemorations are not new on the Kirchberg Plateau where the Court has its headquarters. Ever since the first ECJ judges left the Court in 1958, 'formal sittings' praising the departing judges and welcoming the newcomers have been held, and the related speeches published by the Court's publishing department.

\footnotetext{
16 The commemorative material gathered for this paper forms a variegated set of documents composed of 15 Festschriften produced between 1981 and 2008 that brought together 511 contributors (nearly half of them are current or former Court members, whether judges, advocates general, or référendaires) on the one hand, and the 92 eulogies written for departing judges and read on the occasion of the Court's formal sittings from the creation of the Court up to 2008, on the other (see the reference list for quoted eulogies).
} 
Yet, from the 1970s onwards, there has been growth in the variety and number of commemorative venues (tributes, jubilees, Festschriften). This development is in part nothing more than the consequence of the gradual reduction in the terms of office of the judges and the arrival of new judges following the various enlargements that automatically multiplied the occurrence of these rites of passage: whereas departures amounted to three in the 1950s, seven in the 1960s, and 10 in the 1970s, they increased to 20 in the 1980s/90s and 32 in the 2000s. But there is more going on here than just an automatic increase. From the mid-1970s onwards, the Court also began celebrating itself as an institution, marking the various anniversaries of its existence - for example, the 25th anniversary in 1976 and the 50th anniversary in 2002, not forgetting the 35th anniversary in 1987 with as many ceremonies and commemorative editions (CJEC, 1976, 1987, 2003). Even more striking is the new genre that has gradually established itself at the Court, namely that of the judicial Festschriften in honor of retiring judges offered by their former colleagues. ${ }^{17}$ Admittedly, some of the professors who were judges at the Court had previously benefited from this tradition (Otto Riese, Riccardo Monaco), but this was usually an offering edited by their former university students in recognition of a long academic career. 1981-82 saw the beginning of what was to become part of the Court's own tradition ${ }^{18}$ : between 1981 and 2008, no less than 15 judges (i.e. nearly one-fourth of the 61 departing judges) were honored with Liber Amicorum, Studi in onore, Mélanges, Festschrift,or even Essays in honor of, either in the year preceding their retirement or in the years following their term of office at the Court. As a result of these concurrent investments, commemorations are no longer exceptional; from the early 1980s onward, they constitute an almost uninterrupted internal practice.

What is first striking when looking at this rich commemorative material is the fact that it is grounded in a particular narrative of the Court's turning points. Interestingly enough, these ritualized celebrations of judges' departures are characterized by a continuous return to the decisions of the Court's 'revolutionary years' (the 1960s), in particular the 'golden age' when the Court delivered its most renowned decisions: Van Gend en Loos and Costa vs. ENEL. For instance, references to the sector-specific jurisprudence of the Court in domains such as

17 The commemorative material gathered for this paper forms a variegated set of documents composed of 15 Festschriften produced between 1981 and 2008 that brought together 511 contributors (nearly half of them are current or former Court members, whether judges, advocates general or référendaires) on the one hand, and the 92 eulogies written for departing judges and read on the occasion of the Court's formal sittings from the creation of the Court up to 2008, on the other (see the reference list for quoted eulogies).

${ }^{18}$ Although the first three recipients of this honor (Hans Kutscher, Jossé Mertens de Wilmars, and Verloren van Themaat) had been adjunct professors and had actively participated in debates on EC law scholarship, none had spent most of their careers in academia. Hans Kutcher had been a judge on the German constitutional court; Jossé Mertens de Wilmars had made a name for himself as a lawyer and as a Christian Democrat politician; and Verloren van Themaat had built a reputation as the first director of DG Competition, a position he held for nearly 12 years. 
non-discrimination, competition, or state aids ritually involves going back to the period of the seminal cases. Hence, the comment by President Iglesias on the occasion of the 50th anniversary of the Court: 'if there was just one judgment that should be cited on this historic occasion, it would without a shadow of a doubt be the Court's decision of 5 February 1963 in the Van Gend en Loos case, which represents the cornerstone of the successive developments of the Community's legal order' (Iglesias in CJEC, 2003: 40-41). However, this return to the source is not so much about remembering the past history of the Court as about constantly reactivating an 'original prophecy'19 that provides the Court and its judges with a timeless truth regarding their role within the European Union. ${ }^{20}$ The heydays of the Court's revolutionary years may well be remote, but they nevertheless form eulogists purport - the enduring message the Court must constantly refer back to in order to remain true to itself. As they are elevated to the statute of an 'original prophecy', they provide lasting cognitive and normative truths about the nature of Europe's judicial power, its office holders and its jurisprudence. Hence, the comment by former judge Pierre Pescatore: 'after the declarations of principle of the 1960s, which put Community law permanently on the right road, came the period of deep immersion in the practical problems which we, as judges of the second or even third generation, have to master' (Pescatore in CJEC, 1980, 1981: $25)$. By working to bridge the gap between current cases and the 'constitutional' cases of the past, by going over the stages of a jurisprudence that remains in line with its first steps, eulogists continuously (re-)design the Court's 'invented tradition' (Hobsbawm and Ranger, 1983), that is, one jurisprudential acquis ${ }^{21}$ consistent over time and across policy domains. By exalting the legal continuity and the unity of its case-law since the 1960s, the eulogists help eclipse the many political ruptures (enlargements, revisions of the treaties) and their effects on the course of the ECJ (increase in the number of judges, changes in its competences, etc.). By constantly placing the construction of current judicial strategies as direct descendants of these two judgments, the tributes therefore grant the Court a truly juridical foundation different to its political origin: eulogists help 'the Court' join the far more stable and 'apolitical' world of 'ordinary' courts and jurisdictions. Thereby, the many different ECJs (the European Court of Coal and Steel born in 1952 from the Paris treaty, the ECJ of the European Communities born in 1958 from the Rome treaties, the current CJEU born in 2009 from the Lisbon treaty) are indeed superseded by one unique 'European Court' characterized by an invariant and trans-historical mission begun 58 years ago in the service of Europe.

\footnotetext{
19 On the analogy with clergymen and religion when studying commemorative undertakings, see the seminal pieces by Pierre Bourdieu (1971) and Peter Berger (1967).

${ }^{20}$ On the building of selective of historical narratives in judicial reasoning and the general tendency of courts to select one privileged account of the past, see the interesting book by Renata Uitz (2005).

21 The index of the judgments cited in certain Mélanges allows one to spot the now spontaneous convergence of its contributors - most of them judges or référendaires - around this jurisprudential acquis'.
} 
Yet, there is more to this 'original prophecy' than just the general willingness to ground ECJ case-law in a distinctively legal tradition. It is integral to the building of a sense of belonging to one unique community whose collective task it is to defend and enrich the Court's jurisprudential acquis. Under the aegis of praising such common judicial patrimony, Festschriften or departure ceremonies symbolically mark the cohesiveness of a group of rather diverse perspectives and backgrounds (national and European, public or private, academics, and practitioners of EU law). Beyond their many differences, ECJ law clerks, judges, senior members of the judiciary from the countries of origin, law firm partners, and renowned academics are reunited through these ritualized occasions. Such a community bond is intensely praised throughout the discourses. By insisting on 'the link that unites us in the memory and the recognition of our great colleague and unforgettable friend' (Iglesias in Iglesias et al., 1999: 19), Festschriften and tributes enable the contours of this symbolic community to be defined and maintained. No doubt the recurrence of the metaphor of the Court as a 'family' and/or as a 'community' takes here its full meaning in order to reactivate a transversal solidarity beyond the multiplicity of differences, or even conflicts, that now afflict the Court as an organization. We are reminded of the 'atmosphere of collegiality, one might even say of brotherhood - since, unfortunately, we (the Court) have only had had one sister' and of 'the congenial rapport between the judges when carrying out their common task' (Due in CJEC, 1995: 156). ${ }^{22}$ Reference is thus made to 'our Court of Justice' (Wathelet in Iglesias et al., 1999: 443). We are told about the congenial atmosphere within the cabinet of each of the judges -'one big happy family' (Hoskins and Robinson, 2004: xv) - and their habitual lunchtime parade to the cantine of the Court: 'we were the first Cabinet to dine en masse, but the Sevóns and the Ragnemalms (other ECJ judges) followed suit'. Some 'disagreements and highly debated questions' (Grevisse in Iglesias et al., 1999: 151) were sometimes on the menu but these would always take the form of a disinterested legal discussion 'based on the esteem and friendship forged in the joint fulfillment of the task of ensuring the observance by all (..) of Community law and thus contributing to the structure of a Community legal order in accordance with the principles of the rule of law' (Mertens de Wilmar in CJEC, 1986: 117). On the whole, the Court is staged as 'a collegiate body made up not of different nationalities but of individual persons' (Ole Due in CJEC, 1990: 61). United despite the diversity of the judicial and extra-judicial functions they carry out in Europe's legal environment (as judges, lawyers, experts, civil servants, professors, etc.), they know and recognize each other as insiders of the Court for which they have worked in the past, present, or future. The apparent multiplicity of points of view contributes to overshadow the reason for the communal presence in the Festschrift, namely their professional experience at the

22 On the issue of gender bias at the European Court of Justice, see Kenney (2002) and Solanke (2008). 
Court and, just as importantly, the subscription to the 'Van Gend en Loos doctrine'. They contribute to identify both in-groups within this circular legitimization and out-groups who are excluded from this process: both experts and laypersons.

\section{Stratifying the court: founding fathers, court spokesmen, and putative heirs}

Within this transnational judicial circle as drawn throughout the Festschriften and tributes, symbolic and material exchanges take place across national, generational, and professional lines. What makes them particularly relevant to our purposes is the fact that current, former, and - as I argue hereafter - future members of the Court are the central players in these venues. They constitute the editors coordinating the written volume in honor of their former (judicial) master or colleague, and the vast majority of the contributors as they are responsible for almost half of the 511 contributions contained in these volumes, with 68 (current or former) ECJ référendaires, 57 former ECJ judges, and 113 current ones. To this number should be added the 21 future judges and advocate generals who took part. Most of the time, a select number of 'founding fathers' whose role in the Court's history is widely recognized are present in the celebration. Their participation (68 of 511 contributions) represents more than just an accolade. Through their presence, they knit an invisible thread that connects all of those, alive or dead, in office or in retirement, who belong to the 'big family' of the Court. Here, the great alumni are not the former university professors, but the survivors of the 'generation of judges of the early 1960s (...), which resolutely worked out the basic principles of our case-law' (Kutscher in CJEC, 1980: 17) and who are thus elevated to the rank of 'founding fathers' of the Court. Among them, Pierre Pescatore is most frequently invited to contribute to these collective publications (4 out of 14). Through his role in the negotiation of the Treaties of Rome, his numerous publications, his 20 years at the Court, and his longevity, he has become one of the main figures of the institution, a genuine trustee of the Community's judicial spirit. His statements show that he embraced this role enthusiastically: 'although for a long time I remained the youngest of the company (of judges), I am now aware of being in Community terms one of the oldest. Indeed today, I have been connected with the Community for exactly 29 years, of which I have spent 18 as a judge' (Pescatore in CJEC, 1986: 170). Other judges of the Court during the 1960s, such as Andreas Donner, Roberto Monaco, or Robert Lecourt, have also been invited to make respective contributions, depending on the nationality of addressee. By their presence, they certify the inter-generational continuity of the Court. By ensuring that the heritage of these 'great alumni' is passed on and that the flame of the 'Van Gend en Loos doctrine' is kept alive, the members of the honorary committee that supervises the Festschriften, most often composed of ECJ judges currently in office, are instituted as the spokesmen of the Court's jurisprudence, as referred to by President Gil Iglesias when he remembered 'our predecessors whose contributions to the Court's rulings remain alive in 
our daily work' (Iglesias in CJEC, 2003: 44). Indeed, the special value of this continuing historic thread stems in particular from the fact that by referring back to those who shaped the Court's history, the new generation of judges is able to perpetuate that history and thus play its role as heirs to the Court's heritage. In other words, the different forms of narrative on the Court's institutional identity also provide the occasion to designate those who can usefully invoke this common judicial heritage. By replicating on their own account 'a university tradition that reserves this rare distinction for the elite of its professors' (CJEC, 1998), the judges of the Court have to some extent copied this rite of passage where alumni and peers both praise and appropriate this heritage together.

Yet, not all current judges or advocate generals benefit from such commemorative undertakings: of the 61 judges that left the Court between 1981 and 2008 , only one-fourth $(n=15)$ were granted such an honor. Those involved in paying these tributes - whether as a speaker during the eulogies (president of the Court or president of Chambers) ${ }^{23}$ or as a member of the Festschriften honorary editorial committee - are the most integrated judges: their position within the Court (presidents or former presidents of the Court or of one of its chambers) and their seniority (an average of 12.6 years) are significantly higher than that of their peers. Such longevity, as illustrated by the Court's former president Lord Mackenzie Stuart, who 'served with no less than 42 Judges and Advocates General, not to mention three Registrars' (Mackenzie Stuart in CJEC, 1989: 201), puts them in a prime position to perceive the threats affecting the Court's perpetuity and react to them. This rite of remembrance may thus be conceived as a means used by a number of judges to establish the legitimacy of their temporal powers (as de facto spokesmen of the ECJ) by becoming the interpreters of the timeless ideals of the Court as embodied by the Court's 'founding fathers'. The rest of the participants (from the law clerks organizing the Feschriften volume to the various authors) in these tributes, those who are neither former nor current judges in Luxemburg are not, however, merely a public attending this transmission ceremony. Most often, they are fellow countrymen or countrywomen of the addressee, reminding us of the double bonds of each of the Court's judges to transnational and national legal circles of EU law practitioners, a feature more generally characteristic of EU law (de Witte, 2008). The participants convened around the addressee thereby form a select group of EU lawyers from the same country sharing a special relationship with the addressee: depending on the latter's original profession, they can be former university colleagues (assistants or acquaintances), former law firm partners (collaborators or associates), or former judicial fellow workers, etc. Yet, although they praise the 'Italian', 'German', or 'French' tradition at the Court, these networks of friendship identify a national pool of persons who possess the

23 The past five presidents - Hans Kutscher, Josse Mertens de Wilmar, John Stuart Mackenzie, Ole Due, and Gil Iglesias - who presided over the Court from 1976 to 2003 have been honored by a Festschrift upon their leaving office. 
professional and social qualities required of those who aspire to eventually inherit this tradition through an appointment at the ECJ. Among the 22 contributors to the Festschriften in honor of Baron Jossé Mertens de Wilmar, all of whom were Dutch speaking (including those of Flemish origin), there were one former judge, five judges in office and three référendaires also in office, and 17 other participants, including two future judges. Thus, the inter-generational bonds forged through these tributes establish genuine national career paths to the Court. The fellow countrymen and former référendaires called upon to celebrate the outgoing judge therefore appear as his natural heirs. Tasked with coordinating the Festschrift for their former master, they stand out as future candidates for the office of EC judge as shown by the fact that from the middle of the 1980s, a growing number of référendaires became judges at the Court. ${ }^{24}$ Far from being illegitimate, these national breeding grounds, through which European judicial capital is accumulated, are often praised in speeches and Festschriften as a mark of excellence. When addressing the outgoing President, the Danish judge Ole Due, Judge Federico Mancini recalled: 'that wonderful essay on the constitutional consequences of the accession of the Kingdom of Denmark to the European Communities which - a sign of destiny - bears, next to your signature, that of our colleague Claus Gulmann who today (22 years later) succeeds you as judge (...) May I add that Mr Gulmann was legal secretary to Max Sørensen, the first Danish judge $(. .$.$) ? Here we have an example of continuity almost virtually unrivaled in$ the 42 years of the Court's existence' (Mancini in CJEC, 1995: 181). All in all, Festschriften and eulogies sanction both contours of a judicial community and its spokesmen, be they 'founding fathers' authoritatively embodying the Court's 'eternal yesterday', spokesmen in charge of leading the Court's currents, or (putative) 'inheritors', with each of these sub-groups calling the other into existence in a sort of continuous cycle of legitimacy.

\section{Profiling the court: paths of EU judicial glory}

The continuous referring back to the Court's jurisprudential acquis also allows the profiling of the Court's formal missions and most-suitable interpreters. Although the Court's members do not participate in the election of their successors, commemorations offer a rare opportunity to publicly set the unofficial parameters for what makes a 'good Community judge'. Indeed, eulogists prefer to suggest ideal types of judges whose specific capacity to adhere to the EU's judicial spirit is highly valued. As a matter of fact, most of time, the recalling of individual

\footnotetext{
24 The phenomenon appeared relatively late, as it was only in 1988 that a former référendaire was for the first time appointed as a judge to the Court. However, this became far more widespread following the creation of the Court of First Instance and the Civil Service Tribunal. Thus, if one takes the 65 judges in office at the Court in 2006, more than one-fifth have previously exercised the role of référendaire at the Court (Grass, 2006: 72).
} 
characteristics only appears in respect of 'individual accomplishments in building a collective undertaking' (Iglesias in CJEC, 2003: 44). Paying his respects in memory of an advocate general who had died a few days earlier, the President of the Court referred to the advocate general's opinions that were published in the Court's reports as follows: 'Karl Roemer's monument surrounds us in this building and it lies on our bookshelves' (Mackenzie Stuart in CJEC, 1986: 161). Each time, the person's life is celebrated as if they were the incarnation par excellence of the legal person that the Court constitutes as a whole. In this regard, the construction of the biography of the judge - of the character-defining moments, the key stages - contributes to the construction of the office of judge at the Court. In this regard, eulogies form a privileged opportunity to define, crystallize, and impose specific criteria of professional worth within the European Court. Most of the time, the spotlight of the commemoration is on the person's role as an accomplished practitioner and a renowned academic, as a typical representative of his or her national legal culture and as a convinced European. In other words, both the 'internal aspect of his responsibilities' and the 'international aspect of his activities' (Iglesias in Iglesias et al., 1999: 17) are remembered. European judicial excellence thus consists of the capacity to combine simultaneously - throughout one's career - an anchorage in one's national legal culture as the basis of the 'representativeness' of the judge within the Community field, together with European (or even international) goodwill. In other words, the Court's judges do not seek to derive legitimacy only from their independence from the groups (including the Member States) that they are meant to judge; indeed, they seek to draw in equal measure upon their attributes as renowned legal scholars and experienced practitioners. This combination is repeatedly underlined as a balancing act: 'Nor at that time of fruitful academic work did Mr Koopmans stand aloof from the world of practical law' (Kutscher in CJEC, 1979: 26). 'It is scarcely possible to imagine a more valuable addition to the Court in the task entrusted to it of declaring the law than this rare blend of experience in an official capacity, legal learning, insight and belief in the great venture which has now united our States and peoples for a generation' (Mertens de Wilmar in CJEC, 1982: 86). This 'wealth of experience will enable (the appointed judge) to discharge to the full the duties of office' (ibid.). Thus, breadth of experience is considered as the key criterion for carrying out the role of judge at the European Court of Justice, over and above the proof of a candidate's independence from those who are the potential subjects of the Court's rulings. It all appears as if the fact of having successively directly represented each of the EC-implicated actors present would give the judge full legitimacy to rule on the disputes among them. In this context, the key factor is reflected in the comment by the German judge Everling with regard to his own career: 'my work always lay on the dividing line between the Community and the Member States. In Brussels I represented German interests and in Bonn I represented Community interests' (Everling in CJEC, 1989: 181). Hence, the 'good ECJ judge' declares neither his pan-European 
beliefs - references to European militancy, a rare thing, disappear almost entirely during the 1990s - nor demonstrates his independence from EU political and social games; instead, he manages to serve equally all the interests that are present in the EU polity while only ever serving the law. This model of excellence was emphasized by Advocate General Van Gerven when he retired from the Court: 'for a jurist who has dedicated his life to the study and the practice of law, in particular to Community law, leaving an institution is nothing out of the ordinary, even if that institution is the Court of Justice. To give up one particular type of legal practice is not to renounce the law. For someone whose ideal is to practice law in varied contexts and in different posts, it is normal to close one chapter and move on to the next. (...) That is what I have been doing for 33 years' (van Gerven in CJEC, 1995: 149). Thus, the model of excellence, which gathers strength with each tribute, praises the European judge as a pontiff of Europe, with the idea that he or she is able to build bridges between the different interests present in the EU polity (François, 1992). In other words, it is through a subtle mixture of proximity to and distance from the groups that confront one another in the construction of the EU that 'the ECJ judge', as represented by the Festschriften and relevant tributes, claims to help the Court reach a position that transcends each of them. In a context where there is no settled definition, nor official criteria, of what it takes to access the Court, such profiling provides role models that wannabe judges are therefore incited to refer to.

\section{Conclusion}

On the whole, the value added of such a sociological turn lies in its analytical ability to trace the many social processes - aggregation into one transnational judicial community and stratification of the latter, inheritance of one's given professional role within that community, self-identification with a professional role, etc. - that happen under the guise of celebrating the Court and its office holders. These jointly social and cognitive processes form a continuous socialization process that help secure and maintain a common sense of what the ECJ is about. In this perspective, the continuous return to the foundational years of the Court is not just a smokescreen, nor a mere public relations strategy aiming at hiding the Court's growing internal heterogeneity. It forms one essential springboard for the transmission of the Court's core beliefs and legal principles to which (former, current, and future) judges are encouraged to refer.

Stepping into the Court in this way allows us to go beyond the classic puzzles of integration theory (What are the dominant forces and actors of Europeanization processes? How did a European Court manage to transcend State sovereignty?), and add new research puzzles in the study of the Court: how can we account for preference formation within the ECJ? What are the social mechanisms through which institutional consistency is produced and reproduced over time in such an international organization? In contrast to the image of the disincarnated and 
homogeneous institution the rationalist paradigm puts forward, the 'social-fabric' approach addresses such questions by opening the Court's black-box and bringing judicial and non-judicial actors, social and professional norms, and historical contexts back into the picture. Courts, I have argued, are not free-floating entities with abstract interests, nor do they survive merely by routine or self-perpetuation. Just as there is no artist without the 'network of cooperation' that makes up the 'art world' famously studied by Howard Becker (1982), so there is no jurisdiction without a 'world' of professionals that has historically emerged and solidified (judges, their legal clerks, private legal practitioners, law professors, etc. see Shapiro, 2002) and a related set of shared beliefs and commonly agreed upon legal principles. In other words, international courts are grounded on a historically built social setting (a specific constellation of actors) and a system of meaning (norms and worldviews). This unpacking of 'the Court' means that, after a decade of large-N statistical accounts of the ECJ (see Conant, 2007), it proves heuristic to engage in fine-grained qualitative studies through which the researcher can look closely at the variety of actors and groups that populate the EU's judicial branch. Despite the Court's many restrictions in providing internal documents, there are many possible ways to follow the concrete social fabrication of the judicial role-set and its instillment among the diverse and heterogeneous group of Court members. Simultaneously, the 'social-fabric approach' allows us to point at stratification processes within the EU judicial community, and in particular at how a transnational elite has been produced and reproduced over time in Luxembourg in spite of the absence of a formalized supranational judicial profession. This foray into the making of the ECJ's leadership may eventually open the way to a renewed narrative of EU legal integration, which has so far remained a rather ahistorical account of disincarnated 'actors' pursuing abstract goals and institutional interests.

\section{Eulogies referred to in the article}

Court of Justice of the European Communities (1976), Judicial and Academic Conference 27-28 September 1976, Luxembourg: OPOCE.

- (1979), Formal Sittings of the Court of Justice, Luxembourg: OPOCE.

- (1980), Formal Sittings of the Court of Justice 1978 and 1979, Luxembourg: OPOCE.

- (1982), Formal Sittings of the Court of Justice 1980-1981, Luxembourg: OPOCE.

- (1986), Synopsis of the Work of the Court of Justice in 1984 and 1985, Luxembourg: OPOCE.

- (1987), XXXV Anni 1952-1987, Luxembourg: OPOCE.

- (1989), Synopsis of the Work of the Court of Justice in 1988 and 1989, Luxembourg: OPOCE.

- (1990), Synopsis of the Work of the Court of Justice in 1990, Luxembourg: OPOCE.

- (1991), Annual Report, Luxembourg: OPOCE.

- (1995), Report of Proceedings 1992-94, Luxembourg: OPOCE.

— (1998), 'Presentation of the Liber Amicorum 'Scritti in onore di G. Federico Mancini'. Press release no. $17 / 98$.

- (2003), 1952-2002. 50th Anniversary of the Court of Justice of the EC. Formal Sitting 4 December 2002, Luxembourg: OPOCE. 


\section{Bibliography}

Alter, K. (2001), Establishing the Supremacy of European Law, Oxford: Oxford University Press.

- (2008), 'Agents or trustees? International courts in their political context', European Journal of International Relations 14(1): 33-63.

Azoulai, L. (2009), 'La Fabrication de la Jurisprudence Communautaire', in P. Mbongo and A. Vauchez (eds), Dans la Fabrique du Droit Européen, Brussels: Bruylant, pp. 153-170.

Becker, H. (1982), The Art Worlds, Berkeley: University of California Press.

Bengoetxea, J. (1993), The Legal Reasoning of the European Court of Justice, Oxford: Clarendon Press.

Bourdieu, P. (1971), 'Genèse et structure du champ religieux', Revue française de sociologie 12(3): 295-334.

- (1987), 'The force of law: toward a sociology of the juridical field', Hastings Law Review 38: $805-853$.

Berger, P. (1967), The Sacred Canopy. Elements of a Sociological Theory of Religion, Garden City: Doubleday.

Burrows, N. (2010) 'The Lisbon Treaty and the Revised Judicial Appointment Processes'. Paper presented at the UACES Conference, Bruges.

Carubba, C.J., M. Gabel and C. Hankla (2008), 'Judicial behavior under political constraint: evidence from the European Court of Justice', American Political Science Review 102(4): 435-452.

Cichowski, R. (2007), The European Court and Civil Society. Litigation and Governance, Cambridge: Cambridge University Press.

Cohen, A. (2008), 'Scarlet Robes, Dark Suits: The Social Recruitment of the European Court of Justice'. Working Paper Series Robert Schuman Center, no. 35.

- (2010), 'Dix Juges en Longue Robe Amarante. La Formation de la Cour de Justice des Communautés Européennes', Revue Française de Science Politique 60(2): 227-446.

Cohen, A. and A. Vauchez (eds) (2010), 'Sociologie politique de l'Europe du droit', Revue Française de Science Politique 60(2): 223-318.

Conant, L. (2007), 'Review article. The politics of European legal integration', Journal of Common Market Studies 45(1): 45-66.

de Witte, B. (2008) European Union Law: A Unified Academic Discipline? EUI Working Paper, Robert Schuman Centre.

Dezalay, Y. and B. Garth (1996), Dealing in Virtue. International Commercial Arbitration and the Construction of a Transnational Legal Order, Chicago: Chicago University Press.

Espeland, W. and T. Halliday (1994), Death becomes them: commémoration, biography and the ritual reconstruction of profession identity among Chicago lawyers in the late XIXth century. Working Paper, Northwestern University.

François, B. (1992), 'Le Président, pontife constitutionnel. Charisme d'institution et construction juridique du politique', in B. Lacroix and J. Lagroye (eds), Le président de la République. Usages et genèses d'une institution, Paris: Presses de la FNSP, pp. 306-329.

Garrett, H. (1995), 'The politics of legal integration in the European Union', International Organization 46(2): 171-181.

Garrett, G., D. Kelemen and H. Schulz (1998), 'The European Court of Justice, national governments, and legal integration in the European Union', International Organization 52(1): 149-176.

Gattini, A. (2009), 'Joined cases Yassin Abdullah Kadi et al. v. Council and Commission, 3 September 2008', Common Market Law Review 46(1): 213-239.

Georgakakis, D. (2010), 'French historical and political sociology of the EU', French Politics 8(2): 437-455.

Granger, M.-P. (2009), 'Les stratégies contentieux des Etats devant la Cour de justice', in P. Mbongo and A. Vauchez (eds), Dans la fabrique du droit européen. Acteurs, scènes et publics de la Cour de justice des communautés européennes, Brussels: Bruylant, pp. 53-104.

Grass, R. (2006), 'Les ressources humaines à la Cour de justice des Communautés européennes', in Mélanges en l'honneur de Philippe Léger. Le droit à la mesure de l’homme, Paris: Pedone, pp. 69-77. 
Grimmel, A. (2010), Judicial Interpretation or Judicial Activism? The Legacy of Rationalism in the Studies of the European Court of Justice. Center for European Studies Working Paper Series, Harvard University, no. 176.

Hennette-Vauchez, S. (2008), Divided in diversity, national scholarship(s) and the European convention on human rights, Robert Schuman Centre Working Papers Series.

Hilbink, L. (2007), Judges beyond Politics in Democracy and Dictatorship, Cambridge: Cambridge University Press.

Hobsbawm, E. and T. Ranger (eds) (1983), The Invention of Tradition, Cambridge: Cambridge University Press.

Hooghe, L. (2005), 'Several roads to international norms, but few via international socialization: a case study of the European Commission', International Organization 59(4): 861-898.

Hoskins, M. and W. Robinson (eds) (2004), A True European. Essays for Judge David Edward, London: Hart Publishing.

Iglesias, G., O. Due and R. Schintgen (eds) (1999), Mélanges en Hommage à Fernand Schockweiler, Baden-Baden: Nomos Verlag.

Jenson, J. and F. Mérand (2010), 'Sociology, institutionalism and the European Union', Comparative European Politics 8(1): 74-92.

Kenney, S. (1998), 'The members of the court of the European communities', Columbia Journal of European Law 5(1): 101-133.

— (2000), 'Puppeteers or agents? What Lazarus's Closed Chambers adds to our understanding of law Clerks', Law and Social Inquiry 25(1): 122-185.

- (2002), 'Breaking the silence: gender mainstreaming and the European Judiciary', Feminist Legal Studies 10: 257-270.

Latour, B. (2009), The Making of Law. An Ethnography of the Conseil d'Etat, New York: Polity Press.

Macalister-Smith, P. and J. Schwietzke (2002), 'Festschriften in public international law: an annotated bibliographical compilation of titles 1930-2000/2001', Nordic Journal of International Law 71(3): 349-430.

Mangenot, M. and J. Rowell (2010), A Political Sociology of the European Union. Reassessing Constructivism, Manchester: Manchester University Press.

Mauss, M. (1897-1898), 'Essai sur la Nature et la Fonction du Sacrifice', L'Année Sociologique 1: 35-138.

McIntosh, W. and C. Kates (1997), Judicial Entrepreneurship. The Role of Judges in the Marketplace of Ideas, Westport: Greenwood Press.

Melchior, L. (1962), 'The importance of legal festschriften for work in international and comparative law', American Journal of Comparative Law 11: 403-411.

Pescatore, P. (2007), Vademecum. Recueil de formules et de conseils pratiques à l'usage des rédacteurs d'arrêts, 3rd édn. Bruylant: Brussels.

Petkova, B. (2010), 'Structural changes and decision-making at the European Court of Justice after the eastern enlargement'. Paper to the ECPR Conference in Dublin.

Rasmussen, H. (2007), 'Present and future European Judicial problems after enlargement and the post2005 ideological revolt', Common Market Law Review 44(6): 1661-1688.

Schepel, H. and R. Wesseling (1997), 'The legal community: judges, lawyers, officials and clerks in the writing of Europe', European Law Journal 3(2): 165-188.

Scharpf, F. (2009), The double asymmetry of European integration or: why the EU cannot be a social market economy, Max Planck Institute. Working Paper 9/12.

Shapiro, M. (2002), 'The success of judicial review and democracy', in A. Stone and M. Shapiro (eds), On Law, Politics and Judicialization, Oxford: Oxford University Press, pp. 149-183.

Scheeck, L. (2010), 'Constitutional activism and fundamental rights in Europe: common interests through transnational socialization', in J. Rowell and M. Mangenot (eds), Political Sociology of the European Union. Reassessing Constructivism, Manchester: Manchester University Press, pp. 109-127.

Solanke, I. (2008), 'Diversity and independence in the European Court of Justice', Columbia Journal of European Law 15: 89-121.

Stone, A. (2004), The Judicial Construction of Europe, Oxford: Oxford University Press. 
- (2010), 'The European Court of Justice and the judicialization of EU governance'. Retrieved 1 February 2011 from http://europeangovernance.livingreviews.org/

Taggart, M. (2002), 'Gardens or graveyards of scholarship? Festschriften in the literature of the common law', Oxford Journal of Legal Studies 22(2): 227-252.

Terris, D., C. Romano and L. Swigart (2007), The International Judge, Brandeis UP, Waltham: Brandeis University Press.

Uitz, R. (2005), Constitutions, Courts and History, Budapest: Central European University Press.

Vauchez, A. (2008a), 'How to become a transnational elite. Lawyers' politics at the genesis of the European communities (1950-1970)', in H. Patersen and M. Madsen (eds), Paradoxes of European Legal Integration, London: Ashgate.

- (2008b), 'The force of a weak field: law and lawyers in the government of the European Union (for a renewed research agenda)', International Political Sociology 2(2): 128-144.

- (2010a), 'The transnational politics of judicialization. Van Gend en Loos and the making of EU polity', European Law Journal 16(1): 1-28.

— (2010b), 'A quoi tient la Cour de justice des Communautés européennes?', Revue française de science politique 60(2): 247-270.

Voeten, E. (2007), 'The politics of international judicial appointments: evidence from the European Court of human rights', International Organization, Fall: 669-701. 